\title{
ブラシレス他励式単相同期発電機の励磁特性
}

\author{
正員柴 田福 夫 (金沢工大) \\ 准 員 小池 伸 一 (金沢工大) \\ 正員 直 江 伸 至 (金沢高専)
}

\section{Excitation Characteristics of Brushless Separate-Exciting Type Single-Phase Synchronous Generator}

Fukuo Shibata, Member, Shinichi Koike, Associate (Kanazawa Institute of Technology), Nobuyuki Naoe, Member (Kanazawa Technical College)

キーワード：発電機，ブラシレス励磁，逆相分回転磁界

\section{1、まえがき}

著者らはさきに，ブラシレス自励単相同期発電 機(1)(2)を提案した。これらの発電機は, 同期発電機本 体に励磁機の機能を内藏させたものであり，その基本 的な特性は既に報告した ${ }^{(2)}$ 。しかし，文献 (2)の発電 機では，回路構成上，分巻特性しかもたないため，機 器設計上工夫が必要である。この設計を適切に行え ば,ある程度の負荷に対して電圧変動率が小さくな り，発電機として有用である。

単相同期機の界磁巻線には，電機子反作用の逆相分 回転磁界により第二調波の交流起電力が誘道される。 この起電力を端子電圧の補偵に利用できれば，負荷特 性が改善される。しかしながら，文献 (2)ではこの逆 相分回転磁界の影響について検討していなかった。

本報告では，逆相分回転磁界を考慮したうえで，他 励式におけるフラシレス単相同期発電機の励磁特性を 解析的および寒験的に検討する。

\section{2.フララシレス他动式単相同期発電機}

图1はブラシレス他励式単相同期発電機の回路図で ある。固定子には，電機子巻線 $W_{a}$ と直流電源 $E_{e}$ が 設けられている。回転子には, 回転子励磁巻線 $W_{e r}$, 界磁巻線 $W_{f}$ 抢よじ回転整流器が設けられている。界 磁巻線は，逆相分回転磁界を吸収させ，端子電圧波形 を正弦波にするために平衡二相巻線になっている。

抵抗負荷時の本発電機の電在方程式は次式となる。

$$
\left[\begin{array}{l}
0 \\
v_{f} \\
v_{f}
\end{array}\right]=\frac{d}{d t}\left[\begin{array}{l}
\psi_{a} \\
\psi_{f t} \\
\psi_{f q}
\end{array}\right]+\left[\begin{array}{lll}
r_{a} 0 & 0 \\
0 & r_{f} 0 \\
0 & 0 & r_{f}
\end{array}\right]\left[\begin{array}{c}
i_{a} \\
i_{f q} \\
i_{f q}
\end{array}\right]+\left[\begin{array}{c}
R \cdot i_{a} \\
0 \\
0
\end{array}\right]
$$

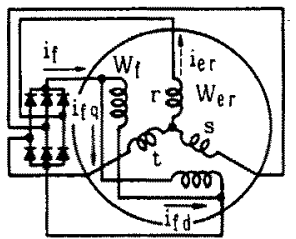

回転子

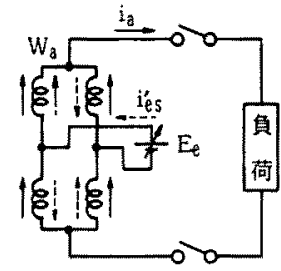

固定子
図 I ブラシレス他励式单相同期発電機の回路

Fig. 1. Circuit diagram of a brushless separate-exciting type single-phase synchronous generator.

各巻線の磁束鎖交数は次式となる。

$$
\begin{aligned}
& {\left[\begin{array}{l}
\psi_{a} \\
\psi_{f d} \\
\psi_{f q}
\end{array}\right]=\left[\begin{array}{ccc}
L_{a} & M_{a r} \cos \theta_{a f} & -M_{a r} \sin \theta_{a f} \\
M_{a f} \cos \theta_{a f} & L_{f} & 0 \\
-M_{a r} \sin \theta_{a f} & 0 & L_{f}
\end{array}\right]} \\
& \times\left[\begin{array}{c}
i_{a} \\
i_{f d} \\
i_{f q}
\end{array}\right]
\end{aligned}
$$

界磁電流は, 回転子励磁巻線と整流器を通して供給 される直流分の界磁電流 $i_{f D}$ と電機子反作用の逆相分 回転磁界に上る第二調波の交流界磁電流 $i_{f A}$ が重畳す る。それぞれの実効值 $I_{f D}, I_{f A}$ は次式となる。 


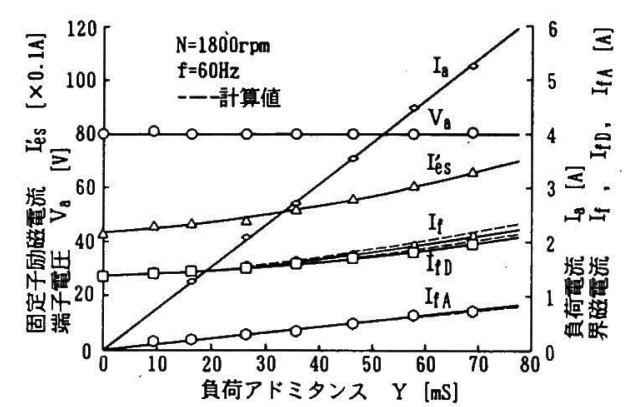

図 2 抵抗負荷特性

Fig. 2. Resistive load characteristics.

$$
\begin{aligned}
I_{f D} & =\frac{6 \sqrt{3} x_{a e} I_{e s}^{\prime}-2 e_{d} \pi}{\pi\left(r_{e r}+R_{f}\right)+6 x_{e r}} \\
I_{f A} & =\frac{x_{a f}^{2} I_{f D}}{4 x_{f} \sqrt{2\left(R^{2}+x_{a}^{2}\right)}}
\end{aligned}
$$

ここで, $x_{a e}=\omega M_{a e}, M_{a e}: W_{a}$ と $W_{e r}$ の間の

相互インダクタンスの最大値, $x_{e r}=\omega L_{e r}$, $R_{f}={ }_{r f} / 2, r_{f}: W_{f}$ の抵抗, $r_{e r}, L_{e r}: W_{e r}$ の 各相の抵抗とインダクタンス, $e_{a}:$ ダイオー ド順方向電圧降下, $R$ : 負荷の抵抗 $\left(r_{a}\right.$ を 含む), $x_{a}=\omega L_{a}, x_{r}=\omega L_{f}$

端子電圧 $v_{a}$ は, 逆相分回転磁界の影響により, 次々に基本波の起電力が誘導され，次式となる。

$$
\begin{aligned}
v_{a}= & v_{a 0}+v_{a 1}+v_{a 2}+\cdots \\
= & \sqrt{2} V_{a 0} \cos \left(\omega t+\phi_{a 0}\right) \\
& +\sum_{n=1}^{\infty} \sqrt{2} V_{a n} \cos \left(\omega t+\phi_{a n}\right)
\end{aligned}
$$

ただし，それぞれの電圧の実効值 $V_{a 0}, V_{a n}$ は,

$$
\begin{aligned}
& V_{a 0}=\frac{x_{a f} R}{2 \sqrt{R^{2}+x_{a}^{2}}} I_{f D} \\
& V_{a n}=\frac{x_{a f}^{2}}{4 x_{f} \sqrt{R^{2}+x_{a}^{2}}} V_{a(n-1)} \\
& \phi_{a n}=\phi_{a(n-1)}-\frac{5}{4} \pi-\tan ^{-1} \frac{x_{a}}{R}
\end{aligned}
$$

\section{3. 実験結果}

実験機は，定格 $2 \mathrm{~kW} ， 220 \mathrm{~V}, 60 \mathrm{~Hz}, 4$ 極の円筒 界磁形同期発電機の二重星形三相電機子巻線の 1 相だ けを使用した。

図 2 は, 固定子励磁電流 $I_{e s}^{\prime}$ を制御した際の負荷特 性を示す。界磁電流の交流分 $I_{f A}$ の実測值は観測波形 から得た值である。計算値は ( 3 )，(4)式に数值を代 入して求めた。計算値と実測值はよく一致している。 $I_{f A}$ は負荷電流 $I_{a}$ に比例していることがわかる。 $I_{f D}$ は $I_{e s}^{\prime}$ に比例しており， $I_{f D}$ と $I_{f A}$ を加えた界磁電流 $I_{f}$ はほほ $I_{f D}$ に等しいことがわかる。

図 3 は, 端子電圧 $v_{a}$, 界磁電流 $i_{f}$ の実測波形およ

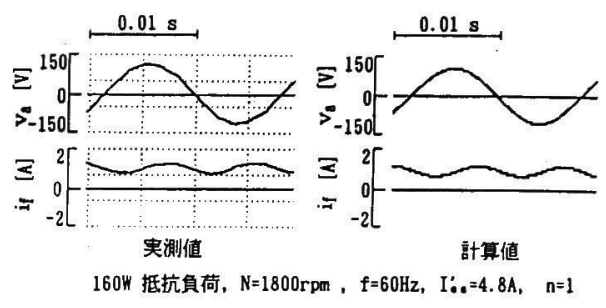

図 3 各部の波形

Fig. 3. Waveforms of part of generator.

び(5)式において逆相分回転磁界の影響を 1 次まで $(n=1)$ とした場合の計算波形を示す。 $v_{a}$ の最大值は

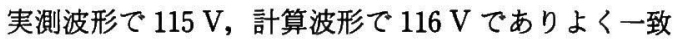
している。 $i_{f}$ は $i_{f D} に i_{f A}$ が重畳することが実測波形 および計算波形からわかる。

4.あとがき

本報告では, ブラシレス他励式単相同期発電機の励 磁特性を電機子反作用の逆相分回転磁界の影響を考慮 して解析と実験により明らかにした。

(平成 4 年 6 月 8 日受付)

$$
\text { 文献 }
$$

(1) F. Shibata : US Patent, No. 3, 573, 578

（2）柴田・直江：「ブラシレス自励正弦波単相同期発電機」, 電学 論 D, 109, 251(平元-4)

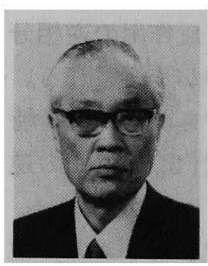
柴田福夫（正員）

大正 13 年 10 月 31 日生。昭和 22 年京 都帝国大学卒業。同年川崎重工入社。現 在, 金沢工業大学電気工学科教授。工学 博士(東京大学)。技術士。IEEE 会員。

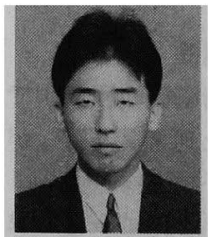

小池 伸 - (准員)

昭和 43 年 11 月 3 日生。平成 3 年 3 月 金沢工業大学電気工学科卒業。現在, 同 大学大学院修士課程電気電子工学専攻在 学中。

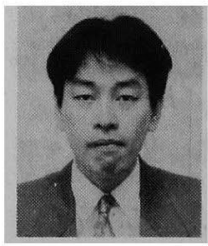

直 江 伸 至 (正員)

昭和 39 年 12 月 27 日生。平成 4 年 3 月金沢工業大学大学院博士課程修了。現 在, 金沢工業高等専門学校電気工学科講 師。工学博士。IEEE 会員。 